\title{
ANALISIS FAKTOR KOMUNIKASI TERHADAP PENGAMBILAN KEPUTUSAN PADA KECAMATAN TANJUNGBALAI UTARA
}

\author{
${ }^{1}$ Gunawan Adiputra Munthe, ${ }^{2}$ Wulan Wardaningtias Putrini, ${ }^{3}$ Nurmala Siregar, ${ }^{4}$ Riski Anggita Akbar Sagala, \\ ${ }^{5}$ Nur Ainun harahap \\ 1,2,3,4,5 Universitas Islam Sumatera Utara \\ Igunawan.adiputra@gmail.com, ${ }^{2}$ wulan.wardaningtias@gmail.com, ${ }^{3}$ nurmala.siregar@gmail.com, \\ ${ }^{4}$ riski.anggit@gmail.com, ${ }^{5}$ nur.ainun@gmail.com
}

\begin{abstract}
This research discusses about the influences of perception, emotion, and knowledge as communication factors on decision making at North Tanjungbalai District. The aim of this research is to analyse the influences of perception, emotion, and knowledge both partially and simultaneously on decision making at the office. This is a quantitative research with random sampling technique. The sample is 44 employees. Results show that each independent variable; perception, emotion, and knowledge, partially influences decision making positively and significantly. perception has tcount value 2,578 and level of significance 0.016, emotion has 3,200 and 0.004, and knowledge has 4,201 and 0.000. Simultaneously, perception, emotion, and knowledge have significant and positive influences on decision making at North Tanjungbalai District with Fcount value 19,355 and level of significance 0.000.
\end{abstract}

Key words: perception, emotion, knowledge, performance, employee.

ABSTRAK : Penelitian ini membahas tentang bagaimana pengaruh persepsi, emosi dan pengetahuan terhadap pengambilan keputusan Kecamatan Tanjungbalai Utara Selatan. Penelitian ini bertujuan untuk menguji pengaruh persepsi, emosi dan pengetahuan baik secara partial maupun simultan terhadap pengambilan keputusan Kecamatan Tanjungbalai Utara Selatan. Penelitian ini merupakan penelitian kuantitatif. Teknik penarikan sampel yang digunakan adalah total sampling dengan menggunakan sampel sebanyak 44 orang pegawai. Hasil penelitian menunjukkan bahwa variabel persepsi memiliki nilai thitung sebesar 4,617 dan signifikansi 0,000, variabel emosi memiliki nilai thitung sebesar 2,346 dan signifikansi 0,024, dan pengetahuan memiliki nilai thitung sebesar 3,559 dan signifikansi 0,001. Dengan demikian dapat dikatakan bahwa secara parsial masing-masing dari persepsi, emosi dan pengetahuan berpengaruh positif dan signifikan terhadap pengambilan keputusan. Secara simultan ketiga variabel tersebut juga berpengaruh positif dan signifikan terhadap pengambilan keputusan Kecamatan Tanjungbalai Utara Selatan dengan nilai Fhitung sebesar 31,734 dan signifikansi 0,000.

Kata Kunci: persepsi, emosi, pengetahuan, pengambilan keputusan, pegawai

\section{Pendahuluan}

Dalam proses pengambilan keputus-an, Kecamatan Tanjungbalai Utara seyogya-nya memberikan kesempatan kepada para pamong untuk terlibat dan berpartisipasi dalam pengambilan dan penetapan putusan. Pemberian kesempatan untuk terlibat dalam pengambilan keputusan ini merupakan suatu hal yang harus ditempuh oleh Kecamatan Tanjungbalai Utara, mengingat posisi dan peran pamong Kecamatan Tanjungbalai Utara merupakan titik sentral yang turut menentukan kualitas kinerja para pegawai.

Pelibatan pamong dan pegawai dalam proses pengambilan dan penetapan keputusan merupakan hal yang penting. Dengan dilibatkannya para pegawai dalam kegiatankegiatan ini dapat mendorong terciptanya iklim dan lingkungan kerja yang positif, memperat hubungan emosional dan hubungan sosial antar sesama, bahkan dapat menjadi sarana menyatukan berbagai pendapat atau persepsi yang berbeda. 
Komunikasi interpersonal merupa-kan suatu bentuk komunikasi dimana seseorang terlibat dalam kegiatan komuni-kasi dengan bertatap muka dengan sese- orang atau dengan sekelompok orang lain-nya. Kemampuan berkomunikasi secara interpersonal merupakan suatu aktifitas yang memerlukan proses untuk dapat sam- pai pada komunikasi yang efektif. Kemam-puan komunikasi interpersonal menuntut seseorang untuk mampu 'mendengarkan' orang lain. Kemampuan komunikasi inter-personal yang baik memungkinkan kita dapat bekerja secara lebih efektif dalam tim atau kelompok baik dalam situasi formal, informal maupun dalam situasi sosial. Komunikasi interpersonal juga dapat membangun hubungan yang kuat dengan orang lain dan menuntun kita pada kemampuan berkomunikasi dengan lebih baik dengan pemahaman yang lebih baik pula.

Kemampuan komunikasi interper-sonal yang baik yang dimiliki oleh seorang pamong dianggap dapat memberikan dampak bagi meningkatnya motivasi kerja pamong. Motivasi merupakan suatu keku-atan potensial yang ada pada diri seseorang manusia, yang dapat dikembangkannya sendiri, atau dikembangkan oleh sejumlah kekuatan luar yang pada intinya sekitar imbalan moneter, dan imbalan non mone-ter, yang dapat mempengaruhi hasil kiner-janya secara positif atau negatif, hal mana tergantung pada situasi dan kondisi yang dihadapi orang yang bersangkutan Motiva-si juga bukan merupakan hal yang mudah dilakukan, karena seorang pimpinan sulit untuk mengetahui kebutuhan (needs) dan keinginan (wants) yang diperlukan oleh seorang bawahan dalam menyelesaikan pekerjaannya.

Motivasi bukan timbul dari dalam diri manusia saja melainkan juga dari kekuatankekuatan lingkungan yang mem-pengaruhi individu untuk melakukan sesu-atu berdasarkan tujuan tujuan yang telah ditetapkan sebelumnya untuk dicapai. Dorongan tersebut dapat berdampak positif maupun negatif bagi individu kalau tidak diarahkan, baik oleh diri sendiri maupun oranglain.

Menurut Davis dan Newstrom (2000: 179), keterlibatan didefinisikan sebagai keterlibatan mental dan emosional orang-orang dalam situasi kelompok yang men-dorong untuk memberikan kontribusi kepada tujuan kelompok dan berbagai tanggung jawab dalam mencapai tujuan tersebut. Ada tiga gagasan penting dalam definisi itu yakni keterlibatan, kontribusi dan tanggung jawab. Keterlibatan mental dan emosional dimaksudkan sebagai keterlibatan psikologis dan egonya yang melebihi keterlibatan fisik. Seseorang pamong yang aktif mengikuti rapat- rapat, pertemuan, selalu dimintai pendapat atasan sementara atasannya adalah pemimpin otokratik maka keterlibatan yang demikian bukanlah keterlibatan. Seseorang yang ber-keterlibatan berarti orang tersebut termo-tivasi untuk memberikan kontribusi, yang diwujudkan dalam bentuk menyalurkan sumber inisiatif dan kreativitasnya guna mencapai tujuan organisasi. lebih dari itu seseorang yang berketerlibatan akan ter-dorong untuk menerima tanggung jawab dalam aktivitas kelompok. Pada saat orang-orang mulai menerima tanggung jawab aktivitas kelompok maka mereka melihat adanya peluang untuk melakukan hal-hal yang mereka inginkan, yaitu merasa bertanggung jawab menyelesaikan pekerjaannya.

Dalam pandangan Brown dan Moberg(2000:483), keterlibatan merupa-kan proses di mana dua orang atau lebih saling memperngaruhi dalam membuat keputusan, yang akan berguna pada waktu mendatang. Lebih lanjut dijelaskan bahwa dalam proses keterlibatan terkandung tiga hal mendasar, yakni pengarahan (direction), konsultasi (consultation) dan delega-si (delegation). Dalam memutuskan suatu hal pemimpin memberikan kesempatan kepada bawahan untuk memberikan ma-sukan namun pada ini keputusan masih berada ditangan pimpinan. Apabila atasan mengijinkan bawahan untuk mengambil keputusan sendiri, maka tingkat yang demikian termasuk delegasi. Pada tingkat ini diperlukan bawahan yang benar-benar menguasai tugas, bertanggung jawab, me-miliki kemampuan yang handal dan memiliki pengalaman sehingga tugas yang didelegasikan dapat diselesaikan dengan sebaik-baiknya.

Keterlibatan adalah pembagian dan keikutsertaan dalam proses pembuatan keputusan kelompok. Keterlibatan yang dimaksud berkaitan dengan siapa, apa, kapan, di mana dan bagaimana. Defenisi tersebut sejalan dengan apa yang dike- mukakan oleh Siagian bahwa pimpinan organisasi bersedia melibatkan bawahan- nya dalam proses pengambilan keputusan bukan hanya yang menyangkut diri sendiri, seperti pekerjaan, jabatan dan penghasilan tetapi mengenai semua aspek kehidupan kekaryaan dalam organisasi. Hal ini dapat dimengerti karena pamong belajar tidak 
mau lagi diperlakukan sebagai alat produk-si semata, melainkan ingin turut serta me-mainkan peranan yang lebih besar dalam pengelolaan organisasi di mana mereka berkarya(Siagian, 2005: 130).

Sesuai dengan kodratnya manusia tidak bisa hidup tanpa orang lain. Sebagai makhluk sosial, setiap manusia memer-lukan kehadiran manusia lain untuk berko- munikasi, berkelompok, saling bantu-membantu dalam memenuhi kebutuhan-nya. Usaha manusia untuk memenuhi kebu-tuhannya itu tidak bisa dilakukan sendiri, sehingga memerlukan bantuan dan kerja sama dengan orang lain. Kondisi demikian mengharuskan manusia berkomunikasi antara yang satu dengan lainnya dalam lingkungan kelompok maupun dalam kehidupan bermasyarakat yang luas.

Komunikasi antar individu yang disebut juga komunikasi interpersonal akan berlangsung efektif dan efisien apabila setiap individu menghormati dan mematuhi norma dan nilainilai yang mengatur perilakunya dalam berkomuni-kasi dengan peran masing-masing dalam kelompoknya. Komunikasi adalah inti dari sebuah interaksi sosial. Tidak mungkin melakukan interaksi sosial tanpa komu-nikasi. Sejak bangun tidur sampai menjelang tidur manusia berkomunikasi dengan orang lain termasuk dengan anggota keluarga, teman sekerja, pimpin-an, relasi dan seterusnya. Komunikasi inter-personal akan berhenti pada saat tidur.

Baron (2003: 489), mendefinisikan bahwa komunikasi dalam proses di mana orang, kelompok atau organisasi mengi-rimkan beberapa informasi kepada orang, kelompok atau organisasi lainnya. Komu-nikasi akan berhasil apabila pesan yang disampaikan komunikator cocok dengan pengalaman dan pengertian yang diperoleh komunikan. Jika pengalaman komunikator sama denganpengalaman komunikan maka komunikasi akan berjalan dengan lancar. Lebih lanjut dinyatakan bahwa komuikator yang berpengalaman akan selalu menaruh perhatian kepada arus balik dan selalu mengubah cara penyampaian pesannya sesuai dengan tanggapan komunikan. Tanggapan arus balik berguna untuk mengontrol sukses tidaknya proses komu-nikasi. Untuk melaksanakan komunikasi menjadi efektif terdapat dua faktor penting pada diri komunikator, yakni kepercayaan (source credibility) dan daya tarik (source atractiveness).
Definisi ini mengisyaratkan bahwa komunikasi setidaknya mengandung tiga gaga-san yakni (1) adanya informasi atau pesan yang akan dikirim, (2) adanya pengirim dan (3) penerima. Pengirim atau penerima dapat berupa manusia atau mesin. Pengirim pesan disebut juga sumber informasi. Dalam suatu organisasi pengi-rim pesan dapat diperankan oleh pimpinan yang sedangmengkomunikasi-kan gagasangagasan kepada para bawahan, sedangkan penerima pesan dapat diperankan oleh seseorang yang baru mendapat penjelasanpenjelasan sehubung-an dengan tugasnya yang baru. Lebih lanjut dikemukakan bahwa komunikasi dalam organisasi dapat dilihat dari sisi komunikasi antarpribadi dan komunikasi organisasi. Komunikasi dapat terjadi ka-rena adanya komponen-komponen, yaitu komunikator yang mengirim pesan (encoded) melalui lambang dalam bentuk bahasa. Selanjutnya pesan disampaikan melalui media dan akhirnya pesan ditrima oleh penerima (recipient) dan selanjutnya pesan tersebut ditafsirkan (decoded) (Rakhmat, 2008: 6).

Komunikasi pada dasarnya adalah penyampaian pesan yang bermakna dari sumber oleh komunikator kepada komuni-kan sebagai alamat. Dalam hal ini Effendi (2006; 34), menyatakan bahwa bila sese-orang berkomunikasi dengan orang lain maka mereka sebenarnya baru menga-dakan "kesamaan" satu sama lainnya. Komunikasi pada hakikatnya adalah hubungan antara komunikator dengan komunikan yang sama-sama sesuai untuk suatu pesan tertentu. Penyampaian pesan yang tepat merupakan dasar pengambilan keputusan.

Menurut Prajudi Atmosudirdjo pengambilan keputusan merupakan inti daripada Kepemimpinan (Leadership), baik kepemimpinan terhadap dirinya sendiri (Self Control) maupun terhadap orang-orang lain (para pengikut) atau terhadap Organisasi (Atmosudirdjo, 1979:1). Mengambil keputusan itu bersifat memilih, yakni memilih di antara berbagai alternatif. Suatu alternatif merupakan suatu tata hubungan (relationship) antara suatu langkah (perbuatan, tindakan) dan akibatnya (efeknya, hasilnya, konsekuensinya).

Pengambilan keputusan terdiri atas beberapa unsur dan sifat antara lain:

a. Harus ada masalah.

b. Masalah berada di dalam suatu situasi dan kondisi.

c. Pengambilan keputusan didahului dengan suatu proses pemikiran: analisa situasi, 
analisa kondisi, analisa masalahnya, menentukan alternatif-alternatif, memikirkan masalah-masalah baru yang akan timbul sebagai efek atau lanjutan daripada setiap alternatif.

d. Pengambilan keputusan merupakan pengakhiran daripada proses pemikiran tersebut di atas dan memilih satu alternatif di antara sekian adanya alternatif.

e. Pengambilan keputusan itu bersifat futuristis (mengenai masa depan atau kemudian).

Manusia merupakan suatu organisma yang paling perasa terhadap iklim psikologis yang mengelilingi kehidupannya. Oleh karena itu para manager atau Decision-Maker harus selalu berusaha membuat iklim yang paling memberikan ketenangan jiwa (dalam segala bentuk) kepada para pelaksana dari pada keputusan- keputusannya. Administrator, Manager, atau Decision-maker dengan prinsipprinsip yang sama harus dapat menggembleng bawahannya untuk mengikuti suatu Administratif Behaviour yang dipola secara tertentu. Dengan demikian maka akan dapat melaksanakan berbagai desisi itu dengan lancar, efektif dan efisien, oleh karena sudah terbiasa dan seirama hidup.

\subsection{Batasan Masalah}

Batasan masalah dimaksudkan untuk membatasi ruang lingkup kajian dalam penelitian. Agar permasalahan yang dikaji terarah maka permasalahan dibatasi dengan hanya mengkaji tentang pengaruh Persepsi, Emosi, dan Pengetahuan terhadap pengambilan keputusan di Kecamatan Tanjungbalai Utara

\subsection{Rumusan Masalah}

Berdasarkan latar belakang masalah dan identifikasi permasalah sebagaimana tersebut di atas, rumusan masalah dalam penelitian ini adalah:

a. Bagaimana pengaruh persepsi terhadap pengambilan keputusan di Kecamatan Tanjungbalai Utara?

b. Bagaimana pengaruh emosi terhadap pengambilan keputusan di Kecamatan Tanjungbalai Utara?

c. Bagaimana pengaruh peuanngetah terhadap pengambilan keputusan di Kecamatan Tanjungbalai Utara?

d. Bagaimana pengaruh persepsi, emosi dan pengetahuan terhadap pengambilan keputusan di Kecamatan Tanjungbalai Utara?

\subsection{Tujuan Penelitian.}

Berdasarkan rumusan masalah penelitian sebagaimana diuraikan di atas, maka tujuan yang hendak dicapai dalam penelitian ini yaitu:

a. Menganalisis pengaruh persepsi terhadap pengambilan keputusan di Kecamatan Tanjungbalai Utara?

b. Menganalisis pengaruh emosi terhadap pengambilan keputusan di Kecamatan Tanjungbalai Utara?

c. Menganalisis pengaruh pengetahuan terhadap pengambilan keputusan di Kecamatan Tanjungbalai Utara?

d. Menganalisis pengaruh persepsi, emosi dan pengetahuan terhadap pengambilan keputusan di Kecamatan Tanjungbalai Utara?

\subsection{Hipotesis}

Hipotesis pada penelitian ini dapat dirumuskan sebagai berikut:

1. Ada pengaruh yang ditampilkan secara parsial persepsi terhadap pengambilan keputusan Kecamatan Tanjungbalai Utara.

2. Ada pengaruh yang ditampilkan secara parsial emosi terhadap pengambilan keputusan Kecamatan Tanjungbalai Utara.

3. Ada pengaruh yang ditampilkan secara parsial pengetahuan terhadap pengambilan keputusan Kecamatan Tanjungbalai Utara.

4. Ada pengaruh yang ditampilkan secara simultan antara persepsi, emosi dan pengetahuan terhadap pengambilan keputusan Kecamatan Tanjungbalai Utara.

\section{Metode Penelitian \\ 2.1. Populasi}

Populasi merupakan suatu kesuluruhan objek yang dapat berupa manusia, benda, makhluk hidup lainnya, gejala atau peristiwa yang memiliki karakteristik dan tempat yang sama dalam waktu tertentu. Menurut Sugiyono (2005), populasi adalah wilayah generalisasi yang terdiri atas objek/subjek yang mempunyai kualitas dan karakteristik tertentu yang ditetapkan oleh peneliti untuk dipelajari kemudian ditarik kesimpulannya. Populasi dalam penelitian ini adalah seluruh pegawai di Kecamatan Tanjungbalai Utara 46 orang. 
Tabel 1 Kerangka Populasi Berdasarkan Jabatan 2021

\begin{tabular}{|r|l|r|}
\hline No & Jabatan & $\begin{array}{c}\text { Jlh } \\
\text { Populasi }\end{array}$ \\
\hline 1 & Camat & 1 \\
\hline 2 & Sekretaris & 1 \\
\hline 3 & Bendahara & 1 \\
\hline 4 & Kepala Seksi & 4 \\
\hline 5 & Kepala Sub. Bagian & 2 \\
\hline 6 & Staf Kecamatan & 4 \\
\hline 7 & Lurah & 5 \\
\hline 8 & Sekretaris Lurah & 5 \\
\hline 9 & Staf Kelurahan & 23 \\
\hline Jumlah & $\mathbf{4 6}$ \\
\hline
\end{tabular}

Sumber: Kecamatan Tanjungbalai Utara, 2021

\subsection{Sampel}

Sampel atau dalam Bahasa Inggris sample adalah bagian dari populasi yang ingin diteliti; dipandang sebagai suatu pendugaan terhadap populasi, bukan bukan populasi itu sendiri. Sampel dianggap sebagai perwakilan dari populasi yang hasilnya mewakili keseluruhan gejala yang diamati. Ukuran dan keragaman sampel menjadi penentu baik atau tidaknya sampel yang diambil.

Sampel dapat dipahami sebagai kumpulan data yang lebih kecil yang dipilih dari populasi yang lebih besar dengan menggunakan metode seleksi yang telah ditentukan. Elemenelemen ini dikenal sebagai titik sampel, unit sampling atau pengamatan. Membuat sampel adalah metode yang efisien dalam melakukan penelitian seperti dalam kebanyakan kasus, tidak mungkin atau sangat mahal dan memakan waktu untuk meneliti seluruh populasi dan karenanya meneliti sampel memberikan wawasan yang dapat diterapkan pada seluruh populasi.

Teknik Sampling adalah suatu cara yang ditempuh dengan pengambilan sampel yang benar-benar sesuai dengan keseluruhan obyek penelitian. Teknik pengambilan sampel dalam penelitian ini adalah total sampling. Total sampling adalah teknik pengambilan sampel dimana jumlah sampel sama dengan populasi, Sugiyono $(2005 ; 34)$. Alasan mengambil total sampling karena menurut Sugiyono jumlah populasi yang kurang dari 100 seluruh populasi dijadikan sampel penelitian semuanya.

Dengan teknik penarikan sampel secara Total Sampling maka sampel dalam penelitian ini adalah seluruh populasi yaitu pegawai di Kecamatan Tanjungbalai Utara sebanyak 44 orang. Sampel ini tidak termasuk Camat dan Peneliti.

Tabel 2 Kerangka Sampel Berdasarkan Jabatan 2021

\begin{tabular}{|r|l|r|r|c|}
\hline \multicolumn{1}{|c|}{ No } & Jabatan & $\begin{array}{c}\text { Jlh } \\
\text { Populasi }\end{array}$ & $\begin{array}{c}\text { Jlh } \\
\text { Sampel }\end{array}$ & Keterangan \\
\hline 1 & Camat & 1 & - & Tidak diteliti \\
\hline 2 & Sekretaris & 1 & 1 & Diteliti \\
\hline 3 & Bendahara & 1 & 1 & Diteliti \\
\hline 4 & Kepala Seksi & 4 & 4 & Diteliti \\
\hline 5 & Kepala Sub. Bagian & 2 & 2 & Diteliti \\
\hline 6 & Staf Kecamatan & 5 & 4 & Diteliti \\
\hline 7 & Lurah & 5 & 5 & Diteliti \\
\hline 8 & Sekretaris Lurah & 23 & 23 & 1 Orang \\
\hline 9 & Staf Kelurahan Jumlah & $\mathbf{4 6}$ & $\mathbf{4 4}$ & \\
\hline \multicolumn{2}{|r|}{ Jum } & & \\
\hline
\end{tabular}

Sumber: Kecamatan Tanjungbalai Utara 2021

\section{Hasil Dan Pembahasan Hasil Penelitian}

\subsection{Uji Validitas}

Pengujian validitas instrumen menggunakan Analysis Correlate Bivariate untuk mencari Correlation Coefficient dari Product Moment Pearson dengan SPSS. Kemudian dibandingkan dengan nilai rtable untuk $\alpha=$ 0.05 dengan derajat kebebasan $(\mathrm{dk}=\mathrm{n}-2)$ sehingga didapat rtable. Untuk butir pernyataan dengan nilai koefisien korelasi (rhitung) $>\mathrm{r}$ table maka butir pernyataan tersebut dinyatakan valid.

Karena jumlah responden yang digunakan untuk uji validitas sebanyak 44 orang, maka nilai rtabel dapat ditentukan dari: $\mathbf{d k}=\mathbf{n}-\mathbf{2}=$ $44-2=42$ 
Nilai $r$ tabel dengan $d k=42$ adalah 0,297. valid jika rhitung $>0,297$.

Oleh karena itu, item pertanyaan dinyatakan

Table 3 Hasil Uji Validitas Variabel Persepsi(X1)

\begin{tabular}{|c|c|c|c|}
\hline Nomor Soal & rhitung & rtabel & Keterangan \\
\hline 1 & 0,654 & 0,297 & Valid \\
\hline 2 & 0,683 & 0,297 & Valid \\
\hline 3 & 0,533 & 0,297 & Valid \\
\hline 4 & 0,591 & 0,297 & Valid \\
\hline 5 & 0,572 & 0,297 & Valid \\
\hline 6 & 0,553 & 0,297 & Valid \\
\hline 7 & 0,637 & 0,297 & Valid \\
\hline 8 & 0,645 & 0,297 & Valid \\
\hline 9 & 0,458 & 0,297 & Valid \\
\hline 10 & 0,665 & 0,297 & \\
\hline
\end{tabular}

Table 4 Hasil Uji Validitas Variabel Emosi (X2)

\begin{tabular}{|c|c|c|c|}
\hline Nomor Soal & rhitung & rtabel & Keterangan \\
\hline 1 & 0,472 & 0,297 & Valid \\
\hline 2 & 0,600 & 0,297 & Valid \\
\hline 3 & 0,770 & 0,297 & Valid \\
\hline 4 & 0,885 & 0,297 & Valid \\
\hline 5 & 0,583 & 0,297 & Valid \\
\hline 6 & 0,442 & 0,297 & Valid \\
\hline 7 & 0,872 & 0,297 & Valid \\
\hline 8 & 0,872 & 0,297 & Valid \\
\hline 9 & 0,786 & 0,297 & Valid \\
\hline
\end{tabular}

Sumber: Data diolah-2021

Table 5.Hasil Uji Validitas Variabel Pengetahuan (X3)

\begin{tabular}{|c|c|c|c|}
\hline Nomor Soal & rhitung & rtabel & Keterangan \\
\hline 1 & 0,373 & 0,297 & Valid \\
\hline 2 & 0,507 & 0,297 & Valid \\
\hline 3 & 0,902 & 0,297 & Valid \\
\hline 4 & 0,877 & 0,297 & Valid \\
\hline 5 & 0,856 & 0,297 & Valid \\
\hline 6 & 0,842 & 0,297 & Valid \\
\hline 7 & 0,877 & 0,297 & Valid \\
\hline 8 & 0,934 & 0,297 & Valid \\
\hline 9 & 0,881 & 0,297 & Valid \\
\hline 10 & 0,507 & 0,297 & \\
\hline
\end{tabular}

Table 6 Hasil Uji Validitas Variabel Pengambilan keputusan(Y)

\begin{tabular}{|c|c|c|c|}
\hline Nomor Soal & rhitung & rtabel & Keterangan \\
\hline 1 & 0,512 & 0,297 & Valid \\
\hline 2 & 0,626 & 0,297 & Valid \\
\hline 3 & 0,560 & 0,297 & Valid \\
\hline 4 & 0,611 & 0,297 & Valid \\
\hline 5 & 0,605 & 0,297 & Valid \\
\hline
\end{tabular}




\begin{tabular}{|c|c|c|c|}
\hline Nomor Soal & rhitung & rtabel & Keterangan \\
\hline 6 & 0,622 & 0,297 & Valid \\
\hline 7 & 0,720 & 0,297 & Valid \\
\hline 8 & 0,705 & 0,297 & Valid \\
\hline 9 & 0,334 & 0,297 & Valid \\
\hline 10 & 0,625 & 0,297 & Valid \\
\hline
\end{tabular}

Sumber: Data diolah-2021

Rekapitulasi Validitas variabel dependen dan independen yang terdapat pada tabel 5.6 hingga 5.9 tersebut di atas seluruh pernyataan dalam setiap variabel memiliki nilai Corrected Item Correlation (rhitung) lebih besar dari rtabel. Dengan demikian, dapat dikatakan bahwa setiap butir pernyataan adalah valid sehingga penelitian ini dapat diteruskan dalam pengujian reliabilitas.

\subsection{Uji Reliabilitas Data}

Pada penelitian ini, uji reliabilitas menggunakan metode Cronbach Alpha. Reliabilitas diukur dengan menguji tingkat konsistensi hasil pengukuran jika dilakukan pengukuran ulang. Andal atau tidaknya suatu data dapat dilihat dari koefisien alpha yang dihasilkan, data yang mendekati angka 1 (satu) dapat dikatakan memiliki keandalan tinggi. Nilai koefisien Cronbach Alpha yang mendekati 1 menunjukkan bahwa hasil yang diperolehsemakin konsisten sehingga dikatakan mempunyai reliabilitas yang tinggi. Suatu data dikatakan akurat jika nilai koefisien cronbach alpha minimum adalah 0,60. Uji reliabilitas pada penelitian ini menggunakan program SPSS versi 20.0.

Table 7 Hasil Uji Reabilitas

\begin{tabular}{|r|c|c|c|}
\hline Variable & $\begin{array}{c}\text { Cronbach's } \\
\text { Alpha }\end{array}$ & N of Items & $\begin{array}{c}\text { Reabilitas } \\
\text { Status }\end{array}$ \\
\hline X1 &, 800 & 10 & Reliabel \\
\hline X2 &, 884 & 10 & Reliabel \\
\hline X3 &, 924 & 10 & Reliabel \\
\hline Y &, 789 & 10 & Reliabel \\
\hline
\end{tabular}

Sumber: Data diolah-2021

Hasil uji reliabilitas yang dilakukan terhadap variabel dependen dan independen seperti tertera pada tabel $5.10 \mathrm{di}$ atas, terlihat bahwa nilai Cronbach Alpha seluruh variabel berkisar antara 0 sampai 1 dan lebih cenderung mendekati angka 1. Dengan demikian keseluruhan item dalam instrumen pengukuran dapat kategorikan sangat reliabel.

\subsection{Uji Asumsi Klasik}

\subsubsection{Uji Normalitas Data}

Pengujian normalitas data bertujuan untuk melihat normal tidaknya sebaran data yang akan dianalisis. Model regresi yang baik adalah distribusi normal atau mendekati normal. Untuk melihat normalitas data ini digunakan pendekatan grafik yaitu Normality Probability Plot. Deteksi normalitas dengan melihat penyebaran data (titik) pada sumbu diagonal dari grafik. dasar pengambilan keputusan (Santoso, 2004: 214), adalah: a. Jika data menyebar disekitar garis diagonal dan mengikuti arah garis diagonal, maka model regresi memenuhi asumsi normalitas.

b. Jika data menyebar jauh dari garis diagonal dan atau tidak mengikuti arah garis diagonal, maka model regresi tidak memenuhi asumsi normalitas.

Pada output SPSS bagian normal P-P Plot of Regresion Standardized Residual, dapat dijelaskan bahwa data-data (titik-titik) cenderung lurus mengikuti garis diagonal sehingga data dalam penelitian ini cenderung berdistribusi normal, seperti terlihat pada gambar di bawah ini. 


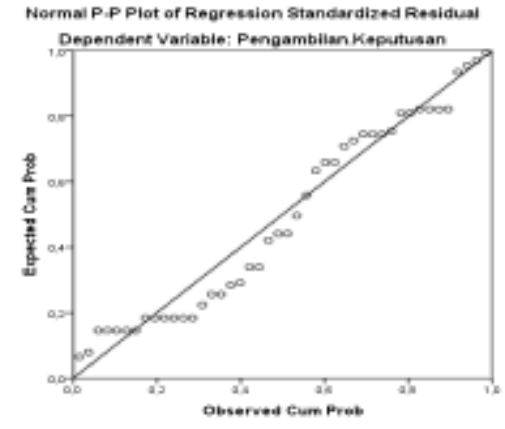

Gambar 1. Normalitas Data

\subsubsection{Uji Multikolinearitas}

Pengujian multikolinearitas dilakukan untuk melihat apakah pada model regresi ditemukan adanya korelasi antara variabel bebas. Jika terjadi korelasi, maka dinamakan terdapat problem multikolinearitas. Cara mendeteksinya adalah dengan melihat nilai Variance Inflation Factor (VIF). Menurut Santoso (2014: 203), pada umumnya jika VIF lebih besar dari 5, maka variabel bebas tersebut mempunyai persoalan multikolinearitas dengan variabel bebas lainnya. Pada ouput SPSS bagian Coefficient, semua angka VIF berada di bawah 5, hal ini menunjukan tidak terjadi multikolinearitas, seperti dapat dilihat pada tabel 5.10 .

Tabel 8. Uji Multikolinearitas

Coefficients $^{\text {a }}$

\begin{tabular}{|l|l|r|r|}
\hline \multicolumn{2}{|l|}{ Model } & \multicolumn{2}{|l|}{ Collinearity Statistics } \\
\cline { 3 - 4 } \multicolumn{2}{|l}{} & Tolerance & \multicolumn{1}{c|}{ VIF } \\
\hline \multirow{4}{*}{1} & (Constant) & & \\
\cline { 2 - 4 } & Persepsi &, 676 & 1,480 \\
\cline { 2 - 4 } & Emosi &, 748 & 1,336 \\
\cline { 2 - 4 } & Pengetahuan &, 805 & 1,242 \\
\hline
\end{tabular}

a. Dependent Variable: Pengambilan.Keputusan

\subsubsection{Uji Heteroskedastisitas}

Pengujian heteroskedastisitas bertujuan untuk melihat apakah dalam sebuah model regresi terjadi ketidaksamaan varians dari residual yang merupakan suatu pengamatan ke pengamatan yang lainnya. Jika varians dari residual yang merupakan suatu pengamatan ke pengamatan yang lain bernilai tetap, maka hasil data disebut homoskedastisitas dan jika varians berbeda atau bernilai tidak tetap maka disebut heteroskedastisitas. Model regresi yang baik adalah model yang bernilai tetap atau homoskedastisitas atau tidak terjadi heteroskedastisitas.

Deteksi heteroskedastisitas dilakukan dengan cara melihat ada tidaknya pola tertentu pada data yang diolah. Menurut Santoso (2014: 208), dasar pengambilan keputusannya adalah:

a. Jika pola tertentu seperti titik-titik yang ada membentuk suatu pola tertentu yang teratur, maka terdapat situasi heteroskedastisitas.

b. Jika tidak ada pola yang jelas, serta titiktitik menyebar di atas dan di bawah angka nol pada sumbu Y, maka tidak terjadi heteroskedastisitas. Pada output SPSS dibagian Scatrerplot, terlihat titk-titik menyebar secara acak, tidak membentuk sebuah pola tertentu yang jelas, serta tersebar baik di atas maupun di bawah angka nol pada sumbu Y. Hal ini berarti tidak terjadi heterskedastisitas pada model regresi, sehingga model regresi layak dipakai. Pola Scatterplot dapat dilihat pada gambar di bawah ini.

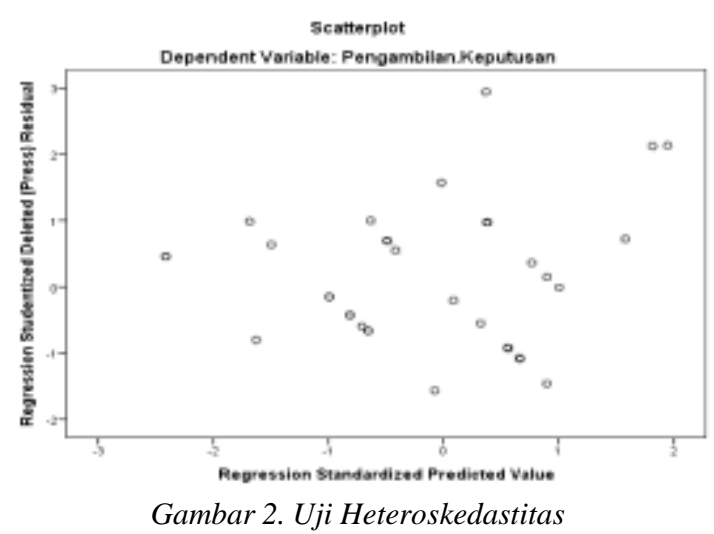

4. Evaluasi Data

\subsection{Pengujian Hipotesis}

Dalam evaluasi data ini penulis akan melakukan pengujian hipotesis, baik secara partial ataupun secara simultan. Selanjutnya untuk mempermudah dalam evaluasi data ini, maka penulis mencari niali-nilai yang dibutuhkan dengan menggunakan perangkat lunak komputer yaitu program SPSS V.20.00 for windows dengan hasil data sebagai berikut: 
Tabel 9 Hasil Uji Statistik Koefisien Regresi

Coefficients ${ }^{\mathbf{a}}$

\begin{tabular}{|c|c|c|c|c|c|c|}
\hline \multirow{2}{*}{\multicolumn{2}{|c|}{ Model }} & \multicolumn{2}{|c|}{$\begin{array}{c}\text { Unstandardized } \\
\text { Coefficients }\end{array}$} & $\begin{array}{l}\text { Standardized } \\
\text { Coefficients }\end{array}$ & $\mathrm{t}$ & Sig. \\
\hline & & $\mathrm{B}$ & Std. Error & Beta & & \\
\hline \multirow{4}{*}{1} & (Constant) & 4,887 & 4,822 & & 1,013 & ,317 \\
\hline & Persepsi & 326 & .071 & 483 & 4.617 & .000 \\
\hline & Emosi & 226 & .096 & 233 & 2.346 & .024 \\
\hline & Pengetahuan & .380 & .107 & 341 & 3.559 & .001 \\
\hline
\end{tabular}

a. Dependent Variable: Pengambilan.Keputusan

Dari tabel 9 di atas dapat dibuat persamaan regresi sebagai berikut:

$$
\mathrm{Y}=4,827+0,326 \mathrm{X} 1+0,226 \mathrm{X} 2+0,380 \mathrm{X} 3
$$$$
+\varepsilon \text {. }
$$

Dari persamaan tersebut dijelaskan bahwa koefesien X1 (Persepsi) mempunyai nilai positif yaitu 0,326 , hal ini menunjukan bahwa variabel Persepsi mempunyai pengaruh positif terhadap variabel Pengambilan keputusan. Koefesien X2 (Emosi) memiliki nilai positif yaitu 0,226 . Hal ini menunjukan bahwa variabel Emosi mempunyai pengaruh positif terhadap variabel Pengambilan keputusan. Koefesien X3 (Pengetahuan) juga memiliki nilai positif yaitu 0,380 . Hal ini menunjukan bahwa variabel Pengetahuan juga mempunyai pengaruh positif terhadap varibel Pengambilan keputusan.

\subsection{Pengujian Secara Simultan (Uji F)}

Hasil pengujian hipotesis secara simultan antara Persepsi, Emosi, dan Pengetahuan terhadap Pengambilan keputusan di Kecamatan Tanjungbalai Utara dapat dilihat pada tabel di bawah ini.

Tabel 10 Hasil Uji Statistik Secara Simultan

\begin{tabular}{|c|c|c|c|c|c|c|}
\hline \multicolumn{7}{|c|}{ ANOVA $^{\mathbf{a}}$} \\
\hline & & Sum of & $\mathrm{df}$ & Mean Square & $\mathrm{F}$ & Sig. \\
\hline \multirow{3}{*}{1} & Regression & 39.368 & 3 & 13.123 & 31.734 & .000 \\
\hline & Residual & 16,541 & 40 & ,414 & & \\
\hline & Total & 55,909 & 43 & & & \\
\hline
\end{tabular}

a. Dependent Variable: Pengambilan.Keputusan

b. Predictors: (Constant), Pengetahuan, Emosi, Persepsi

Dari tabel 10 di atas dapat diketahui denngan jelas bahwa nilai Fhitung adalah 31,734 dan nilai signifikansi 0,000. Diketahui nilai Ftabel dengan tingkat kepercayaan 95\% $(\alpha: 0,05)$ adalah 2,840 . Oleh karena itu nilai Fhitung> Ftabel $\left(31,734>2,840\right.$ maka $\mathrm{Ho}_{\mathrm{o}}$ ditolak dan menerima hipotesis dalam penelitian ini yaitu bahwa Persepsi,, Emosi, dan pengetahuan berpengaruh positif dan signifikan terhadap Pengambilan keputusan di Kecamatan Tanjungbalai Utara.

\subsection{Pengujian Secara Parsial (Uji t)}

Tabel 11 Hasil Uji Parsial Variabel X Terhadap Y

\section{Coefficients ${ }^{\mathrm{a}}$}

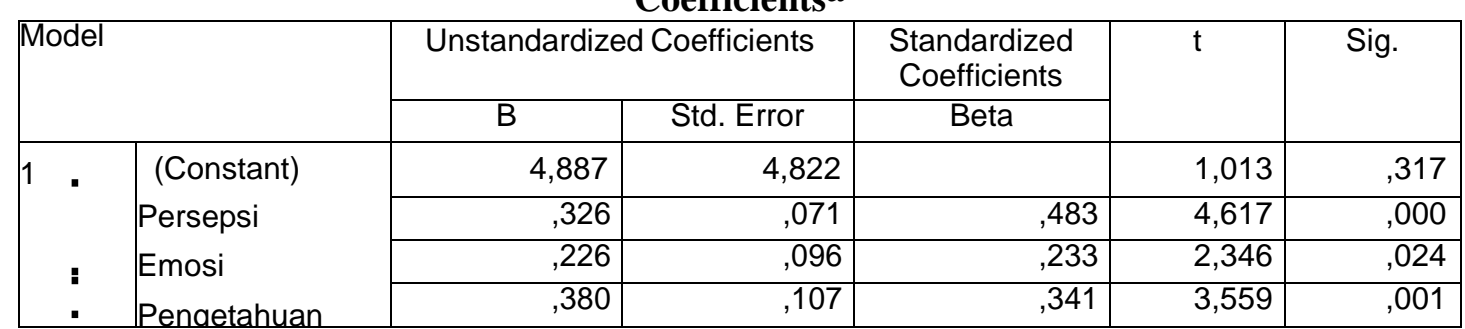

a. Dependent Variable: Pengambilan.Keputusan

\subsection{Pengaruh $X 1$ terhadap $Y$}

Secara parsial pengaruh Persepsi (X1) terhadap Pengambilan keputusan (Y) dapat diketahui dengan memperhatikan data pada tabel 5.14 di atas. Berdasarkan tabel tersebut diperoleh nilai thitung sebesar 4,617 dan 
nilai signifikansi 0,010 . Sedangkan nilai tabel pada tingkat kepercayaan $95 \%(\alpha: 0,05)$ adalah 2,021 . Oleh karena itu nilai thitung $>$ ttabel $(4,617>2,021)$ maka $\mathrm{H}_{\mathrm{O}}$ ditolak dan menerima hipotesis dalam penelitian ini yaitu variabel Persepsi berpengaruh positif terhadap Pengambilan keputusan di Kecamatan Tanjungbalai Utara.

\subsection{Pengaruh $X 2$ terhadap $Y$}

Secara parsial pengaruh Emosi (X2) terhadap Pengambilan keputusan (Y) dapat dilihat pada tebel 5.14 di atas. Berdasarkan tabel tersebut diperoleh nilai thitung sebesar 2,347 dan nilai signifikansi 0,024 . Sedangkan nilai ttabel pada tingkat kepercayaan 95\% ( $\alpha$ : $0,05)$ adalah 2,021. Oleh karena itu nilai thitung $>$ ttabel $(2,347>2,021)$ maka Ho ditolak dan menerima hipotesis dalam penelitian ini yaitu Emosi berpengaruh positif terhadap Pengambilan keputusan di Kecamatan Tanjungbalai Utara.

\subsection{Pengaruh $X 3$ terhadap $Y$}

Untuk mengetahui secara parsial pengaruh pengetahuan (X3) terhadap Pengambilan keputusan (Y) dapat dilihat pada tebel 5.14 di atas. Berdasarkan tabel tersebut diperoleh nilai thitung sebesar 3,559 dan nilai signifikansi 0,001 . Sedangkan nilai ttabel pada tingkat kepercayaan $95 \%(\alpha: 0,05)$ adalah 2,021 . Oleh karena itu nilai thitung $>$ tabel $(3,559>2,021)$ maka $\mathrm{H}_{\mathrm{o}}$ ditolak dan menerima hipotesis dalam penelitian ini yaitu variabel Pengetahuan berpengaruh positif terhadap Pengambilan keputusan di Kecamatan Tanjungbalai Utara.

\subsection{Uji Koefisien Determinasi $\left(\mathbf{R}^{2}\right)$}

Uji determinan digunakan untuk mengetahui seberapa besar pengaruh variabel independen terhadap variabel dependen. Untuk melihat hasil uji determinan maka dapat diketahui nilai $\mathrm{R}$ Square atau koefesien determinasi dapat dilihat di bawah ini.

Tabel 12 Model Summary

Model Summaryb

\begin{tabular}{|l|r|r|l|r|r|r|}
\hline Model & $\mathrm{R}$ & R Square & $\begin{array}{l}\text { Adjusted R } \\
\text { Square }\end{array}$ & \multicolumn{1}{|c|}{$\begin{array}{l}\text { Std. Error of } \\
\text { the Estimate }\end{array}$} & \multicolumn{2}{|c|}{ Change Statistics } \\
\cline { 6 - 7 } & & & & & R Square Change & F Change \\
\hline $\mathbf{1}$ &, $8399^{\mathrm{a}}$ &, 704 &, 682 &, 64306 &, 704 & 31,734 \\
\hline
\end{tabular}

a. Predictors: (Constant), Disiplin, Budaya.organisasi, Komitmen.organisasi

b. Dependent Variable: Kinerja.pegawai

Pada tabel di atas dapat diketahui bahwa Nilai R Square adalah 0,704. Hal ini menunjukan bahwa $70,40 \%$ variabel Pengambilan keputusan di Kecamatan Tanjungbalai Utara dapat dijelaskan oleh variabel Persepsi, Emosi, dan Pengetahuan sedangkan sisanya sebesar $29,60 \%$ tidak dilakukan penelitian.

\section{Kesimpulan}

Dari hasil uji yang dilakukan dapat disimpulkan bahwa:

1. Variabel Persepsi, Emosi dan Pengetahuan secara parsial atau sendirisendiri berpengaruh positif dan signifikan terhadap Pengambilan keputusan di Kecamatan Tanjungbalai Utara. Variabel Persepsi memiliki nilai thitung sebesar 4,167 dan signifikansi 0,000. Variabel emosi memiliki nilai thitung sebesar 2,346 dan signifikansi 0,024 dan pengetahuan memiliki nilai thitung sebesar 3,559 dan signifikansi 0,001.

2. Pengujian yang dilakukan terhadap variabel persepsi, emosi dan pengetahuan secara bersama-sama atau simultan berpengaruh positif dan signifikan terhadap pengambilan keputusan di Kecamatan Tanjungbalai Utara dengan nilai sebesar 31,734 dan signifikansi level 0,000.

3. Nilai $\mathrm{R}$ Square adalah 0,704 . Hal ini menunjukan bahwa 70,40\% variabel Pengambilan keputusan di Kecamatan Tanjungbalai Utara dapat dijelaskan oleh variabel Persepsi, Emosi, dan Pengetahuan sedangkan sisanya sebesar $29,60 \%$ tidak dilakukan penelitian

\section{DAFTAR PUSTAKA}

Abdul Rahmat. 2014. Hubungan Keterlibatan Pamong dalam Pengambilan Keputusan dan Komunikasi Interpersonal Dengan Motivasi Kerja Pamong paket C Di Bpk 
bprovinsi Gorontalo. Psympathic, Jurnal Ilmiah Psikologi.

file:///C:/Users/SASTRA 1/AppData/Local/ Temp/474-857-1-PB.pdf.

Ainun Marddyah Siregar. 2016. Peran Komunikasi dalam Pengambilan

Keputusan

Berimigras.

file:///C:/Users/SASTRA 1/AppData/Local/

Temp/PERAN\%20KOM

UNIKASI\%20DALAM\%20PENGAMBILA N\%20KEPUTUSAN\%20

BERIMIGRASI.pdf.

Anzizhan, Syafaruddin. 2004. Sistem Pengambilan Keputusan Pendidikan. Jakarta: PT Grasido.

Ardiyanto, Elfinaro dan Komala Erdinaya Lukiati. 2005.Komunikasi Massa Suatu Pengantar. Bandung: PT Remaja Rosdakarya Offset.

Arni, M. 2005. Komunikasi Organisasi. Jakarta: Bumi Aksara.

Arwani (eds.). 2002. Komunikasi dalam Keperawatan. Jakarta: Buku Kedokteran EGC.

Atmosudirdjo, Prajudi, 1979. Pengambilan Keputusan (Decision Making). Jakarta: UI.

Desmita. 2009. Psikologi Pembangunan. Bandung: PT Remaja Rosdakarya

Effendy, Onong Uchjana. 2000. Ilmu Komunikasi Teori dan Praktek. Bandung: Alfabeta.

Faraqi, Fahmi. 2015. Pengaruh Kelompok Referensi dan Efikasi Diri Terhadap Pengambilan Keputusan Dalam Memilih Jurusan Kedokteran Siswa Kelas XII IPA SMA N 1 Samarinda.Jurnal Fakultas Ilmu Sosial dan Politik. Vol. 4, No.1. Hal $731-740$. Samarinda: Universitas Mulawarman.

Handoko T. 2002. Manajemen Personalia dan Sumber Daya Manusia. Edisi. II. Cetakan Keempat Belas. Yogyakarta: BPFE.

Lusia Handayani, dkk. 2017. Peran Komunikasi Dalam Proses Pengambilan Keputusan Bermigrasi. Jurnal Komunikasi Pembangunan. file:///C:/Users/SASTRA 1/AppData/Local/ Temp/22801- Article\%20Text-69572-1-1020180814.pdf.

Mahmud. 2010. Psikologi Pendidikan. Bandung: Pustaka Setia.
Mulyana, Deddy. 2005. Ilmu Komunikasi:

Suatu Pengantar. Cetakan ke 18. Bandung: PT. Remaja Rosdakarya,

Munandir. 1996. Program Bimbingan Karier Di Sekolah. Jakarta: Departemen Pendidikan Dan Kebudayaan Direktoral Jenderal Pendidikan Tinggi Proyek Pendidikan Tenaga Akademik.

Musliha \& Fatmawati, S. 2010.

Komunikasi Keperawatan Terapeutik, Yogyakarta: Nuha Medika.

Notoatmodjo, Soekidjo. 2005. Metodologi

Penelitian Kesehatan, Jakarta: PT Rineka. Cipta.

Potter \& Perry Terbitan. 2006. Buku

Ajar Fundamental Keperawatan:

Konsep, Proses, dan Praktik. Jakarta: EGC.

Resmin Sihotang. 2015. Hubungan Antara

Komunikasi Dan Pengambilan

Keputusan Dengan Kinerja Kepala

Sekolah Dasar Negeri Di Wilayah

Jakarta Timur. Jurnal Manajemen

Pendidikan.

https://media.neliti.com/media/publications/ 113192-ID-hubungan- antara-komunikasidan-pengambil.pdf.

Rodiyah, St. 2013. Partisipasi Masyarakat

Dalam Pengambilan Keputusan dan

Perencanaan di Sekolah. Yogyakarta:

Pustaka Pelajar.

Sugiyono. 2005. Metode Penelitian Administrasi. Bandung: Alfabeta. Supranto, 2005. Teknik Pengambilan Keputusan. Jakarta: PT Rineka Cipta. Suryani. 2005. Komunikasi Terapeutik: teori dan praktik. Jakarta: EGC. Syamsi, Ibnu. 2002. Pengambilan Keputusan dan Sistem Informasi. Jakarta: Bumi Aksara.

Vardiansyah, Dani \& Erna Febriani. 2017. Pengantar Ilmu Komunikasi. Jakarta:

Penerbit Ghalia Indonesia

Wahono, R.S. (2001). Pengantar Manajemen

Organisasi. Jakarta: EGC. 